\title{
Ecology and seasonal variation of parasites in wild Aequidens tetramerus, a Cichlidae from the Amazon
}

\author{
Marcos Tavares-Dias ${ }^{*}$, Marcos Sidney Brito Oliveira², \\ Raissa Alves Gonçalves ${ }^{2}$ and Luis Maurício Abdon Silva ${ }^{3}$ \\ ${ }^{1}$ Embrapa Amapá, Aquaculture and Fishery Laboratory, 68903-419, Macapá, Amapá State, Brazil; \\ ${ }^{2}$ University of Amapá State (UEAP), 68906-970, Macapá, Amapá State, Brazil; \\ ${ }^{3}$ Institute of Scientific and Technologic Researches from Amapá State (IEPA), 68901-025, Macapá, Amapá State, Brazil
}

\begin{abstract}
This study is the first investigation on seasonal dynamics of parasites component community of the Aequidens tetramerus from an Amazon River tributary, in Northern Brazil. A total of 239,2407 parasites were recovered from 92 hosts examined from February to October 2011. Such parasites included Ichthyophthirius multifiliis, Tripartiella tetramerii and Trichodina nobilis (Protozoa), Dolops longicauda (Argulidae), Gussevia alioides, Gussevia disparoides (Monogenoidea), Digenea metacercarie, Pseudoproleptus larvae, Anisakidae larvae (Nematoda), Proteocephalidea plerocercoid (Eucestoda) and Gorytocephalus spectabilis (Acanthocephala). Ciliates were the most dominant and abundant taxon, while cestodes were the least prevalent. The parasites showed seasonal variation in their infection dynamics associated with environmental changes during the Amazonian drainage season, except the infection with I. multifiliis. The parasites community in A. tetramerus was also characterized by higher diversity, species richness and uniformity during the drainage season when compared to Amazon flood season. With the exception of T. tetramerii, these parasite species are new records for A. tetramerus.
\end{abstract}

\section{Keywords}

Cichlid, ectoparasites, freshwater fish, diversity, seasonality

\section{Introduction}

The Cichlidae are interesting fishes because of their evolutionary diversity, morphological, ecological and behavioral variation, as well as the biogeographic distribution (Farias et al. 2000, Sparks 2004). Also, cichlid species have great economic importance to aquaculture (Mathews et al. 2013). Aequidens tetramerus Heckel, 1840 (Cichlasomatinae) is endemic cichlid to South America, being widely distributed in the Amazon River basin in Peru, Colombia, Ecuador, Brazil and Bolivia, Guyana, French Guyana and Orinoco River basin from Venezuela and Colombia (Ferreira et al. 1998, Kullander 2003). This cichlid species popularly known as "saddle cichlid" or "saddleback acara" inhabits rivers and stream systems of these basins and it is one of the most colorful species of the genus, especially during its reproduction period (Boujard et al. 1997). It used as ornamental fish species, sport fiing and also as food for the Amazon riverine populations.

Tropical river systems with dynamic flooding and drying strongly influence communities of invertebrates and fish, as well as the aquatic vegetation. While there are no significant differences in water quality among rivers, lakes and wetland during the dry season, the diversity of zooplankton and invertebrates is higher in lakes and wetlands (Nhiwatiwa et al. 2009). In the Amazon, seasonal variation in water level is influenced mainly by seasonal rains in the Andinean region, cause of periodic flooding of marginal areas. The exchange of materials between terrestrial and aquatic ecosystems affects the proportion of suspended and dissolved material and the physical-chemical characteristics of the water bodies (Affonso et al. 2011). Therefore, it is important to determine the roles of different parasite species within a community, if their infection levels are constant and if environmental variations caused by the seasonal dry/rainy cycle influences the availability of intermediate host and can lead to consequent alterations in the recruitment processes of parasites species. This cycle also affects the feeding behavior of hosts (ViolanteGonzález et al. 2008) by modifying its exposure to certain parasite species, and it may lead to changes in the community structure of parasites from the host fish. 
Few investigations have evaluated the effects of seasonality on parasite communities of fish species from Amazon lakes (Vital et al. 2011, Neves et al. 2013); however, no study investigated the tides influence in the estuarine region of the Amazon River system. In the eastern Amazon (Northern Brazil), the tributaries of Amazon River have strong influence of tides of this river. The Amazon River tides (every 12 hours) play important role on fish communities, but such influences on the parasite communities and infracommunities have not been studied in this ecosystem, as well as the effects of and rainfall seasons. Such information is important to understand the parasite ecology, how fish species can provide insights into the different habitats that parasites may occupy and also how the hosts' history might be affected by different parasites in this Amazon ecosystem.

Fish is a good source of quality protein, but diverse parasitic diseases may cause threat to wild and farmed fish population, leading to economic losses in fish farms and fisheries. Studies on the seasonal occurrence of parasites may indicate periods during which epizootic outbreaks are likely to be favored, and such knowledge is extremely important to prevent economic losses for fisheries. This study evaluated the influence of seasonality on parasites community structure from A. tetramerus of a tributary of the Amazon River in Brazil.

\section{Materials and Methods}

\section{Study area}

The study was conducted in Igarapé Fortaleza basin $\left(00^{\circ} 00^{\prime} 56.3 \mathrm{~N}, 051^{\circ} 05^{\prime} 27.1 \mathrm{~W}\right)$, tributary of the Amazonas River, near Macapá city in State of Amapá, eastern Amazon region. The Igarapé Fortaleza basin is a system formed by one major channel and rich wetland systems influenced by the Amazon rainfall and tides from the Amazonas River. Regional vegetation consists of plants characteristics of floodplain forests and periodically flooded herbaceous fields, composed mainly of various macrophyte species (Thomaz et al. 2003). The climate is typical of the tropical rainforest, with maximum rainfall rates during the summer and spring (December to May), and minimum during the winter and autumn (June to November) (Souza and Cunha 2010). This seasonality, based on the periods of drainage and flood, promotes transition to the wetland system among vegetation, land, and water, creating a very dynamic ecosystem. During the flood and drainage seasons, the temperature, oxygen level and $\mathrm{pH}$ were measured by using digital devices for each purpose. Pluviometric indices were obtained from the Institute of Scientific and Technologic Researches from Amapá State (IEPA).

\section{Fish and parasites sampling}

Aequidens tetramerus specimens were captured monthly in the major channel and wetlands from February to October 2011, with appropriate gillnets and transported to the laboratory on ice for parasites examination. A total of 92 A. tetramerus were caught, measured for total length $(\mathrm{cm})$ and weighed $(\mathrm{g})$. All specimens were examined for ectoparasites (eyes, gills and mouth cavity) and for endoparasites (liver, kidney and digestive tract). Parasites were fixed, preserved and stained according to standard techniques (Amato et al. 1991, Eiras et al. 2006). Parasite metazoans were counted under stereomicroscope, and the protozoans by using a Sedgewick-Rafter chamber. Trichodinid and monogenoidean species were counted in combination due to difficulty to separate each species.

\section{Data analysis}

The parasitological terminology used throughout follows that of Bush et al. (1997) and the prevalence, intensity and mean abundance were used to analyze the parasite community. Statistical analyses were performed only for those parasite species with prevalence higher than $10 \%$. The index of dispersion (ID) and Poulin's discrepancy index (D), computed by using the software Quantitative Parasitology 3.0, were employed to detect the distribution patterns of the parasite infracommunity (Rózsa et al. 2000). The following parasite community descriptors were calculated at infracommunity level: species richness, Brillouin's diversity index $(H B)$, Evenness $(\mathrm{E})$, dominance index of BergerPark $(d)$ and relative frequency (percentage of infracommunities whose species was numerically dominant) were determined (Rohde et al. 1995, Magurran 2004) by using the software Diversity (Pisces Conservation Ltda, UK).

Differences in parasite prevalence of each species in A. tetramerus were evaluated using the Chi-Square test $\left(\chi^{2}\right)$ with the Yates correction, and in abundance using the MannWhitney $U$-test (Zar 2010). The Shapiro-Wilk test was used to determine whether parasite abundance data followed a normal distribution pattern. Differences in parasite species diversity and between flood and drainage seasons were evaluated by using the Mann-Whitney $U$-test (Zar 2010). Pearson coefficient (r) was used to determine correlations of length and weight with the parasites diversity, index $(H B)$, evenness of diversity $(E)$, dominance $(d)$ and species richness (Zar 2010).

Body weight $(\mathrm{g})$ and total length $(\mathrm{cm})$ were used to calculate the condition factor (K-Allometric) of fish using the length-weight relationship $\left(\mathrm{W}=\mathrm{aL}^{\mathrm{b}}\right)$ after logarithmic transformation of length and weight and subsequent adjustment of two straight lines, obtaining $\ln y=\ln A+B \ln x$ (Le Cren 1951). Condition factor mean values of overall fish, and fish dry and flood season were compared using the Kruskal-Wallis test $(\mathrm{KW})$. Statistical tests were performed using the software Sigma Stat.

\section{Results}

During the flood season, mean rainfall $( \pm$ SD), mean temperature, oxygen and mean $\mathrm{pH}$ were: $319.8 \pm 92.59 \mathrm{~mm}, 29.5 \pm$ 
$0.3^{\circ} \mathrm{C}, 2.6 \pm 0.3 \mathrm{mg} / \mathrm{L}$ and $6.1 \pm 0.4$, respectively. During the drainage season, mean rainfall, mean temperature and mean pH were: $128.2 \pm 121.0 \mathrm{~mm}, 30.5 \pm 0.3^{\circ} \mathrm{C}, 2.0 \pm 0.3 \mathrm{mg} / \mathrm{L}$ and $6.3 \pm 0.3$, respectively.

\section{Parasite component communities}

From 92 individuals of $A$. tetramerus collected (mean length of $14.1 \pm 2.1 \mathrm{~cm}$, and range of 10.0-19.2 cm; mean weight of $64.8 \pm 25.2 \mathrm{~g}$, and range of $21.7-157.5 \mathrm{~g}$ ) a total of 2.392.407 parasites were collected. The parasites belonging to 11 different taxa, comprising 3 ciliophorans, 1 branchiuran, 2 monogenoideans, 1 digenean, 2 nematodes, 1 acanthocephalan and 1 cestode (Table I). Out of all the fish samples, $100 \%$ were parasitized with at least one parasite species. The protozoan I. multifiliis was the most prevalent, abundant and dominant species, followed by Tripartiella tetramerii and Trichodina nobilis. Protozoa was the most dominant and abundant taxon in A. tetramerus. Species of Gussevia alioides and Gussevia disparoides (Dactylogyridae), digenean metacercariae and the nematode Pseudoproleptus sp. larvae (Cystidicolidae) were also prevalent. However, branchyuran Dolops longicauda (Argulidae), and anisakid larvae (Anisakidae), acanthocephalans Gorytocephalus spectabilis (Neoechinorhynchidae), and the Proteocephalidea larvae exhibited the lower prevalence value. All parasite species showed aggregate dispersion, but I. multifiliis had the lowest dispersion rate (Table I).

In A. tetramerus, none of the parasite species exhibited normal pattern of distribution for abundance values. The parasite species richness was $2.5 \pm 1.7$ ( $1-7$ per fish), diversity index of Brillouin $0.28 \pm 0.28(0-0.75)$, evenness $0.13 \pm 0.13$ $(0-0.34)$ and dominance index $0.85 \pm 0.16(0.5-1.0)$.

For hosts, growth was negative allometric $\left(\mathrm{b}=2.487, \mathrm{r}^{2}=\right.$ 0.813 ) and body weight was positively related to total length $(\mathrm{r}=0.821, \mathrm{p}<0.001)$. This negative allometric growth indicates greater increase in body weight than in size. Overall condition factor of fish was not different $(\mathrm{H}=3.256, \mathrm{p}=0.196)$ in drainage and flood seasons (Fig. 1), indicating similar body conditions, although the hosts weight in drainage season (56.8 $\pm 17.6 \mathrm{~g})$ had been significantly $(U=708.5, \mathrm{p}=0.020)$ lower than in flood season $(69.7 \pm 27.5 \mathrm{~g})$.

Aequidens tetramerus length showed weak positive correlation with the abundance of I. multifiliis $(\mathrm{r}=0.236, \mathrm{p}=$ 0.023 ), but a weak negative correlation with abundance of $T$. tetramerii and T. nobilis $(\mathrm{r}=-0.232, \mathrm{p}=0.026)$ and abundance of $G$. alioides and $G$. disparoides $(\mathrm{r}=-0.233, \mathrm{p}=0.025)$. Fish length was negatively correlated with diversity index of Brillouin $(\mathrm{r}=-0.425, \mathrm{p}=0.0001)$, evenness of diversity $(E)(\mathrm{r}=$ $-0.424, \mathrm{p}=0.0001)$, dominance $(d)(\mathrm{r}=0.416, \mathrm{p}=0.0001)$ and species richness $(r=-0.347, p=0.0007)$. Hosts weight showed weak positive correlation with the abundance of I. multifiliis $(\mathrm{r}=0.259, \mathrm{p}=0.012)$, but a weak negative correlation with the abundance of T. tetramerii and T. nobilis $(\mathrm{r}=$ $-0.219, \mathrm{p}=0.035)$. However, the abundance of $G$. alioides and $G$. disparoides was not correlated with the weight $(\mathrm{r}=$ $-0.157, \mathrm{p}=0.136$ ) of fish. Weight of A. tetramerus had correlation with the species richness $(r=-0.320, p=0.002)$, diversity index of Brillouin $(r=-0.420, p=0.0001)$, evenness of diversity $(\mathrm{r}=-0.416, \mathrm{p}=0.0001)$ and dominance $(\mathrm{r}=0.386$, $\mathrm{p}=0.0001)$.

\section{Seasonal variation in infracommunities of parasites}

There was variation in the parasite richness between flood and drainage seasons; diversity index $(H B)$, evenness of diversity $(E)$ and parasite species richness had higher values during the drainage season. In contrast, the dominance index $(d)$ was higher during the flood season (Table II).

Infection with $I$. multifiliis exhibited no seasonal variation once the high prevalence and abundance occurred during the flood and seasons. In contrast, the highest prevalence and abundance of trichodinids (T. tetramerii and T. nobilis) and monogenoideans (G. alioides and G. disparoides) was during the drainage season. However, infection with digenean metacercariae, anisakid larvae, Proteocephalidea larvae, Pseudoproleptus sp. and G. spectabilis occurred only during the drainage season (Table III).

Table I. Site of infection (SI), prevalence (P), mean intensity (MI), and mean abundance (MA) \pm SD, dispersion index (ID), index of discrepancy (D) and frequency of dominance (FD) of parasites collected from Aequidens tetramerus $(\mathrm{n}=92)$ in eastern Amazon, Northern Brazil

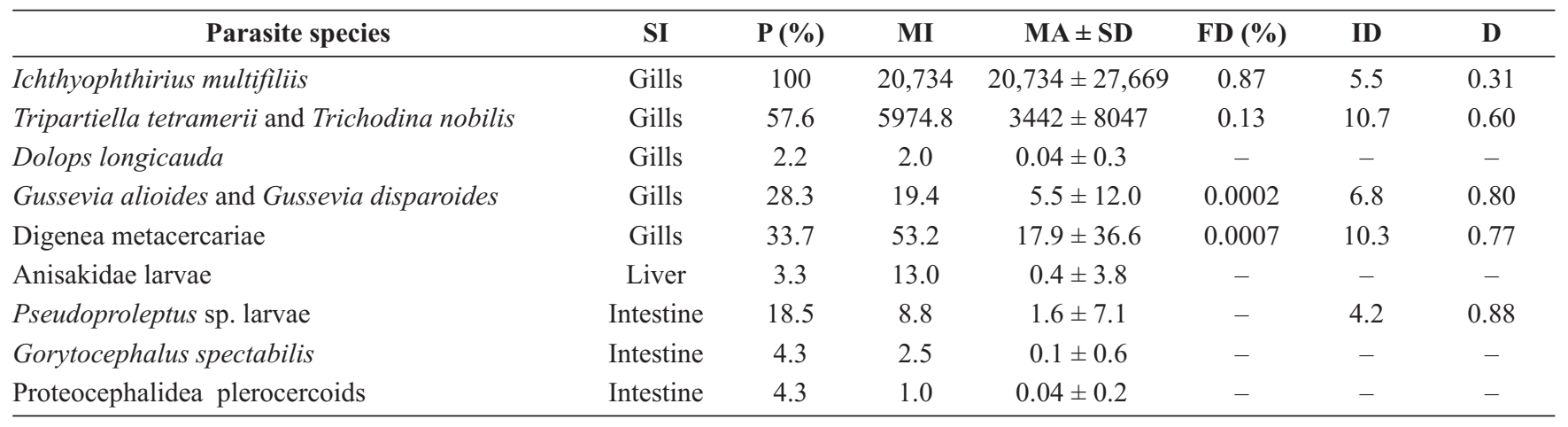




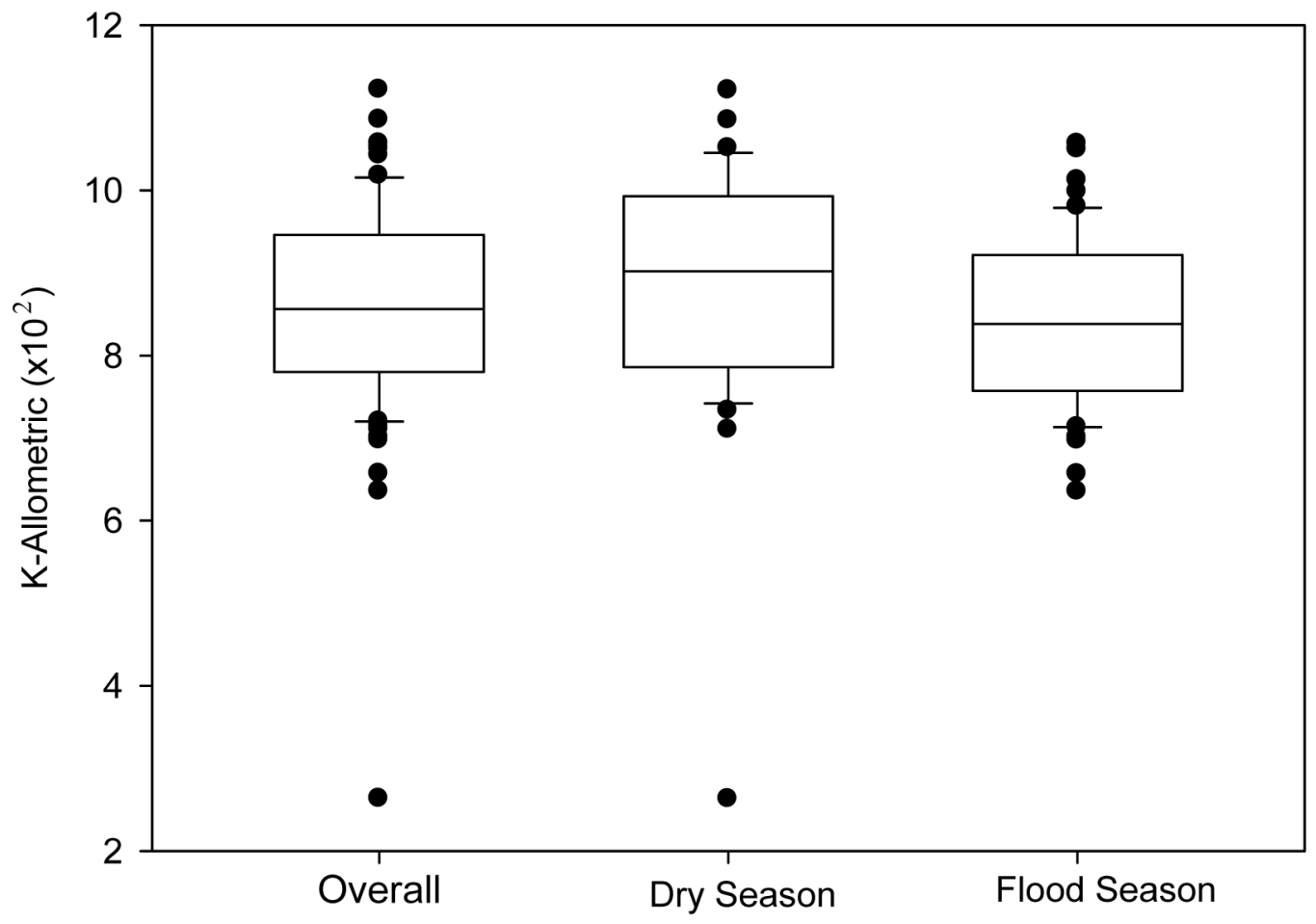

Fig. 1. Condition factor of Aequidens tetramerus collected in eastern Amazon, Northern Brazil (box plots represent medians, interquartile ranges, minimum-maximum ranges and outliers). Equal mean values according to the Kruskal-Wallis test ( $\mathrm{p}>0.05)$

Table II. Differences in infracommunities parameters between drainage $(\mathrm{n}=35)$ and flood $(\mathrm{n}=57)$ seasons for parasites collected from Aequidens tetramerus in eastern Amazon, Northern Brazil. U: Mann-Whitney test

\begin{tabular}{lccrr}
\hline \multicolumn{1}{c}{ Diversity indices } & Drainage season & Flood season & $\boldsymbol{U}$ & $\boldsymbol{p}$ \\
\hline Parasites species richness & $4.5 \pm 1.2(2-7)$ & $1.3 \pm 0.5(1-2)$ & 18.0 & 0.0001 \\
Mean Brillouin index $(H B)$ & $0.52 \pm 0.20(0.09-0.75)$ & $0.12 \pm 0.21(0-0.67)$ & 0.0001 \\
Mean evenness index $(E)$ & $0.24 \pm 0.09(0.04-0.34)$ & $0.06 \pm 0.10(0-0.31)$ & 181.0 & 0.0001 \\
Mean Berger-Parker index $(d)$ & $0.74 \pm 0.15(0.50-0.98)$ & $0.95 \pm 0.10(0.60-1.00)$ & 198.00 & 0.0001 \\
\hline
\end{tabular}

Table III. Differences in prevalence $(\mathrm{P})$ and mean abundance $(\mathrm{MA}) \pm \mathrm{SD}$, between drainage $(\mathrm{n}=35)$ and flood $(\mathrm{n}=57)$ seasons for parasites collected from Aequidens tetramerus $(\mathrm{n}=92)$ in eastern Amazon, Northern Brazil. $U=$ Mann-Whitney test coefficient, $\chi^{2}=$ Chi-Square test. $* \mathrm{p}<0.05 ; * * \mathrm{p}<0.001$

\begin{tabular}{|c|c|c|c|c|c|c|}
\hline Parasite species & \multicolumn{2}{|c|}{ Drainage season } & \multicolumn{4}{|c|}{ Flood season } \\
\hline Ichthyophthirius multifiliis & 100 & $21,415.7 \pm 17,962.8$ & 100 & $23,225.2 \pm 32,355.3$ & 0 & 922.0 \\
\hline Dolops longicauda & 5.7 & $0.1 \pm 0.5$ & 0 & 0 & - & - \\
\hline Gussevia alioides and Gussevia disparoides & 74.3 & $14.4 \pm 15.9$ & 19.3 & $2.0 \pm 4.4$ & $27.271 * * *$ & $403.5^{* *}$ \\
\hline Pseudoproleptus sp. & 48.6 & $4.3 \pm 11.1$ & 0 & 0 & - & - \\
\hline Gorytocephalus spectabilis & 11.4 & $0.3 \pm 0.9$ & 0 & 0 & - & - \\
\hline Proteocephalidea larvae & 11.4 & $0.1 \pm 0.3$ & 0 & 0 & - & - \\
\hline
\end{tabular}




\section{Discussion}

In $A$. tetramerus, the parasite community consisted of 11 protozoan and metazoan taxa, but only 4 of those were endoparasites of which $80.0 \%$ were larvae. This parasite community was dominated by the ciliates I. multifiliis, T. tetramerii and T. nobilis, all ectoparasites considered typical of the lentic environment. However, none of the parasites had been reported parasitizing A. tetramerus, once this is the first study for such Amazonian cichlid, and it showed seasonal variation in parasitic infection.

Body size of $A$. tetramerus was positively correlated with the abundance of $I$. multifiliis, and negatively correlated with the abundance of T. tetramerii and T. nobilis. Such protozoans are common obligate parasites due to their small size, high reproductive and infection rates (Neves et al. 2013). However, the condition factor was not influenced by seasonality, since juveniles and adults $A$. tetramerus were collected during both drainage and flood seasons.

High infection of digenean metacercariae was observed in gills of $A$. tetramerus. However, the infection with monogenoideans was moderate, while low infection of $D$. longicauda, anisakid larvae, Pseudoproleptus sp., G. spectabilis and Proteocephalidea plerocercoid was found. In addition, I. multifiliis, trichodinid (T. tetramerii and T. nobilis), monogenoideans ( $G$. alioides and $G$. disparoides), digenean metacercariae and Pseudoproleptus sp. larvae had over dispersed distribution, a common dispersion pattern in fish (Rohde et al. 1995; Moller 2006; Neves et al. 2013).

Studies on parasite fauna of $A$. tetramerus are scarce. The digenean Creptotrema lynchi was reported infecting this host from Peruvian Amazon (Curran 2008), but no information on infection levels was mentioned. Some parasites found here in A. tetramerus have also been reported for other fish species, including Amazon cichlids. Gussevia alioides and G. disparoides were reported for Heros severum from Amazon River (Kritsky et al. 1986), D. longicauda in Characiformes and Siluriformes species and freshwater stingray (Chemes and Takemoto 2011) and G. spectabilis for two Curimatidae species (Santos et al. 2008). Pseudoproleptus larvae have been reported in the cichlid Satanoperca jurupari, a paratenic host of this nematode species because the prawn Macrobrachium amazonicum is a first intermediate host in Amazonas River delta (Melo et al. 2011). Anisakid larvae are the most common in nematodes of Brazilian freshwater fish (Luque et al. 2011). In contrast, T. tetramerii is a trichodinid specific to A. tetramerus, while $T$. nobilis, an exotic parasite that was introduced together with the non-native host Oreochromis niloticus in the region this study.

It has been hypothesized that component endohelminths communities in many tropical freshwater fish consist of lower species richness and have lower infection rate than fish from certain areas of temperate regions (Choudhury and Dick 2000). Our findings partly corroborate this idea since low endohelminths abundance was found in A. tetramerus. However, as fish are host parasites with varied life strategies, therefore the diversity and abundance of these parasites can depend on different factors, including seasonality (Choudhury and Dick 2000, Kadlec et al. 2003, Violante-González et al. 2008, Neves et al. 2013).

Aequidens tetramerus is a benthopelagic fish, juveniles live associated with roots of aquatic macrophytes during the drainage season in the Amazon (Prado et al. 2009). This cichlid frequently inhabits areas with weak currents and over substrates covered with vegetative debris, and feeds primarily on insects, secondarily on plants, aquatic invertebrates and fishes (Santos et al. 2004, Hurtado-Gonzales et al. 2010). Parents take care of juveniles and are known to be very territorial fish (Hurtado-Gonzales et al. 2010). Therefore, as A. tetramerus is an omnivorous host occupying intermediate level in the food web, thus it has lower risk of infection than carnivorous and piscivorous fish that occupy the top of this web. However, this host had helminths species accounting on most part from its parasite fauna. The main factors responsible for structuring this parasite community in fish population have been predominantly the host behavior, availability of infective stages in the environment and seasonality (Violante-González et al. 2008; Vital et al. 2011; Neves et al. 2013).

Although various investigations (Choudhury and Dick 2000, Kadlec et al. 2003, Violante-González et al. 2008, Adriano et al. 2012) have evaluated the seasonality effects on parasite communities of different fish species from tropical or temperate climate areas, such studies are scarce in the Amazon region. For $A$. tetramerus, the present results show that the parasites diversity, species richness and evenness were higher during the drainage season, since most of parasite species occurred only in the drainage season. In contrast, the parasite richness of $A$. ocellatus was not different between flood and drainage seasons, because most species occurred during both sampling periods, while diversity and dominance were higher in the flood season (Neves et al. 2013). Environmental factors caused by the drainage season seem to have contributed to the presence of digenean metacercariae, anisakid larvae, Proteocephalidea larvae, Pseudoproleptus larvae and G. spectabilis, and the increased abundance of $T$. tetramerii and $T$. nobilis and $G$. alioides and $G$. disparoides in A. tetramerus. Such increase in prevalence and abundance of parasites in wild fish during the dry season may be due to increased hosts density and greater overlap of intermediate and definitive hosts in a shrunken environment (Choudhury and Dick 2000), facilitating the transmission of parasites with complex life cycle as anisakid larvae and Pseudoproleptus sp., Proteocephalidea larvae and G. spectabilis.

In $A$. tetramerus, parasites species richness, diversity and evenness of diversity decreased with the increased host body size, in contrast to results reported for Astronotus ocellatus, a cichlid from Pracuúba Lake, in the eastern Amazon (Neves et al. 2013). This indicates that the host body size was also important determinant of variation in parasites species richness and diversity among the $A$. tetramerus population. This influenced the parasitism of I. multifiliis in A. tetramerus that 
occurred during both seasons, as well as the higher prevalence and abundance of T. tetramerii and T. nobilis and G. alioides and $G$. disparoides during the drainage season. In contrast, for A. ocellatus from Pracuúba Lake, the prevalence and abundance of I. multifiliis, Trichodina sp., Gussevia asota, G. rogersi and larvae of Contracaecum (Neves et al. 2013). On the other hand, the infection of I. multifiliis and Trichodina species in Zungaro jahu from Pantanal (Brazil) was not affected by the drainage or flood seasons (Adriano et al. 2012).

The Igarapé Fortaleza basin has environmental conditions strongly influenced by daily tides from the Amazon River and by constant input of organic matter, which is influenced by the delta of this river system and also by urban eutrophication. This eutrophication is higher during drainage season when there is nitrate, phosphate and ammonia (Takiyama et al. 2004). Such environmental conditions in this so unique Amazonian ecosystem have a strong role on communities and infracommunities of the ectoparasites and endoparasites in A. tetramerus, thus they induced a different response in the drainage season. However, in Pracuúba Lake, a habitat for the A. ocellatus, unstable environmental conditions occur during the drainage season due to a drastic reduction of water levels (Silveira and Santos 2006), while the environmental conditions are more stable during the rainy season and lead to the formation of a floodplain. During the rainy season, the availability of food resources for A. ocellatus is increased by rainfall, affecting the distribution of Contracaecum infective stages, a trophically transmitted species. In addition, the appearance of a floodplain favored the reproduction of these ectoparasites with direct life cycle during the rainy season. In the Amazon, the lake-floodplain systems may change the population dynamics of native fauna, mainly invertebrate and fish populations, with direct or indirect influence on structure and species composition of parasites in fish, as well as on the host life (Vital et al. 2011).

Finally, the fish parasite communities have strong interaction with the environment, host fish, and aquatic invertebrate communities, thus, factors that are directly involved in their different life cycles, such as different host populations, different environments, can cause different responses to seasonal fluctuations in water level. Therefore, the main factors structuring the parasite infracommunities of $A$. tetramerus are the hydrodynamic variation, host feeding behavior and seasonal variation in the availability of parasites infective stages in the environment. These factors influenced the structure of parasites infracommunities primarily through accumulation of protozoans and monogenoideans during the drainage season, and temporarily either through the accumulation of anisakid larvae, G. spectabilis and cestodes plerocercoid or through ingestion of these endoparasites during the rainy season.

Acknowledgements. The present work was developed according to the principles adopted by Brazilian College of Animal Experiments (COBEA) and under the authorization from ICMBio (\# 23276-1). M. Tavares-Dias was supported by a Research fellowship from Conselho Nacional de Pesquisa e Desenvolvimento Tecnológico (CNPq, Brazil).

\section{References}

Adriano E.A., Ceccarelli P.S., Silva M.R.M., Maia A.A.M. 2012 Prevalência, distribuição geográfica e sazonal de protozoários e mixozoários parasitos de jaú (Zungaro jahu) no Pantanal Matrogrossense. Pesquisa Veterinária Brasileira, 32, 1341-1344.

Affonso A.G., Barbosa C., Novo E.M.L.M. 2011. Water quality changes in floodplain lakes due to the Amazonas River flood pulse: Lago Grande de Curuaí (Pará). Brazilian Journal of Biology, 71, 601-610.

Amato J.F.R., Walter A.B., Amato S.B. 1991. Protocolo para laboratório. Coleta e processamento de parasitas do pescado. $1^{\mathrm{a}} \mathrm{ed}$. Imprensa Universitária, Universidade Federal Rural do Rio de Janeiro, Seropédica, Brazil, 81 pp.

Boujard T., Pascal M., Meunier J.F., Le Bail P.Y. 1997. Poissons de Guyane. Guide écologique de l'Approuague et de la réserve des Nouragues. Institut National de la Recherche Agronomique, Paris, 219 pp.

Bush A.O., Lafferty K.D., Lotz J.M., Shostak W. 1997. Parasitology meets ecology on its own terms: Margolis et al. Revisited. Journal of Parasitology, 83, 575-583.

Eiras J.C., Takemoto R.M., Pavanelli G.C. 2006. Métodos de estudo e técnicas laboratoriais em parasitologia de peixes. $2^{\mathrm{a}} \mathrm{Ed}$. Eduem, Maringá, 199 pp.

Chemes S.B., Takemoto R.M. 2011. Diversity of parasites from middle Paraná system freshwater fishes, Argentina. International Journal of Biodiversity and Conservation, 3, 249-266.

Choudhury A., Dick T.A. 2000. Richness and diversity of helminth communities in tropical freshwater fishes: empirical evidence. Journal of Biogeography, 27, 935-956.

Curran S.S. 2008. Two new species of Creptotrema (Digenea: Allocreadiidae) from South America. Revista Mexicana de Biodiversidad, $79,15 \mathrm{~s}-21 \mathrm{~s}$.

Farias I.P., Ortí G., Meyer A. 2000. Total evidence: molecules, morphology, and the phylogenetics of cichlid fishes. Journal of Experimental Zoology, 288, 76-92.

Ferreira E.J.G., Zuanon J.A.S., Santos G.M. 1998. Peixes comerciais do médio Amazonas. Ibama, Manaus, 211 pp.

Hurtado-Gonzales J.L., Baldassarre D.T., UY J.A.C. 2010. Interaction between female mating preferences and predation may explain the maintenance of rare males in the pentamorphic fish Poecilia parae. Journal of Evolutionary Biology, 23, 1293-1301.

Kadlec D., Simková A., Jarkovsky J. 2003. Parasite communities of freshwater fish under flood conditions. Parasitology Research, 89, 272-283.

Kritsky D.C., Thatcher V.E., Boeger W.A. 1986. Neotropical Monogenea. 8. Revision of Urocleidoides (Dactylogyridae, Ancyrocephalinae). Proceedings of the Helminthological Society of Washington, 53, 1-37.

Kullander S.O. 2003. Cichlidae (Cichlids). In: Eds. Reis R.E, Kullander S.O, Ferraris Jr. C.J. (Checklist of the Freshwater Fishes of South and Central America. EDIPUCRS, Porto Alegre, 605-654.

LeCren C.D. 1951. The length-weight relationship and seasonal cyclein gonad weight and condition in perch, Perca fluviatilis. Journal of Animal Ecology, 20, 201-209.

Luque J.L., Aguiar J.C., Vieira F.M., Gibson D.I., Portes-Santos C. 2011. Checklist of Nematoda associated with the fishes of Brazil. Zootaxa, 3082, 1-88.

Magurran A. E. 2004. Measuring biological diversity. Blackwell Science, Oxford,UK, 256 pp.

Mathews P.D., Mertins O., Mathews J.P.D, Orbe R.I. 2013. Massive parasitism by Gussevia tucunarense (Platyhelminthes: Monogenea: Dactylogyridae) in fingerlings of bujurqui-tucunare 
cultured in the Peruvian Amazon. Acta Parasitologica, 58 223-225. DOI: 10.2478/s11686-013-0129-7.

Melo M.F., Giese E.G., Santos J.N., Portes Santos C. 2011. First record of Pseudoproleptus sp. (Nematoda: Cystidicolidae) in fish host. Acta Tropica, 117, 212-215.

Moller A.P. 2006. Parasitism and the regulation oh host populations. In: Thomas, F., Renaud, F., Guégan, J.F. Parasitism and ecosystems. Oxford University Press, New York, 43-53.

Neves L.R., Pereira F.B., Tavares-Dias M., Luque J.L. 2013. Seasonal influence on the parasite fauna of a wild population of Astronotus ocellatus (Perciformes: Cichlidae) from the Brazilian Amazon. Journal of Parasitology, 99, 718-721. DOI: 10.1645/12-84.1.

Nhiwatiwa T., Bie T.D., Vervaeke B., Barson M., Stevens M., Vanhove M. P. M., Brendonck L. 2009. Invertebrate communities in dry-season pools of a large subtropical river: patterns and processes. Hydrobiologia, 630, 169-186.

Prado L.K., Freitas E.C., Oliveira S.A. 2009. Assembléias de peixes associadas a diferentes bancos de macrófitas aquáticas em lagos de várzea do baixo Rio Solimões. Revista Colombiana de Ciências Animal, 1, 185-201.

Rohde K., Hayward C., Heap M. 1995. Aspects of the ecology of metazoan ectoparasites of marine fishes. International Journal for Parasitology, 25, 945-970.

Rózsa L., Reiczigel J., Majoros G. 2000. Quantifying parasites in samples of hosts. The Journal of Parasitology, 86, 228-232.

Santos C.P., Gibson D.I., Tavares L.E.R., Luque J.L. 2008. Checklist of Acanthocephala associated with the fishes of Brazil. Zootaxa, 1938, 1-22.

Santos G.M., Mérona B., Juras A.A., Jégu M. 2004. Peixes do baixo Rio Tocantins: 20 anos depois da Usina Hidrelétrica Tucuruí. Eletronorte, Brasília, 216 pp.

Silveira O.F.M., Santos V.F. 2006. Aspectos geológicos-geomorfológicos região costeira entre o Rio Amapá Grande e a região dos Lagos do Amapá, In: Eds. Costa-Neto S.V. Inventário bio- lógico das áreas do Sucuruju e região dos Lagos no estado do Amapá. IEAP, Macapá, 17-40.

Souza E.B.; Cunha A.C. 2010. Climatologia de precipitação no estado do Amapá e mecanismos climáticos de grande escala. In: Eds. Cunha A.C., Souza E.B., Cunha H.F.A Tempo, clima e recursos hídricos: resultados do Projeto REMETAP no estado do Amapá.IEPA, Macapá, 177-195.

Sparks J.S. 2004. Molecular phylogeny and biogeography of the Malagasy and South Asian cichlids (Teleostei: Perciformes: Cichlidae). Molecular Phylogenetics and Evolution, 30, 599614.

Takiyama L.R., Silva A.Q., Costa W.J.P., Nascimento H.S. 2004. Qualidade das águas das ressacas das bacias do Igarapé da Fortaleza e do Rio Curiaú In: Eds. Takiyama L.R., Silva A.Q. Diagnóstico das ressacas do Estado do Amapá: bacias do Igarapé da Fortaleza e Rio Curiaú, Macapá-AP. CPAQ/IEPA e DGEO/SEMA, Macapá, 81-104.

Thomaz D.O., Costa Neto S.V., Tostes L.C.L. 2003. Inventário florístico das ressacas das bacias do Igarapé da Fortaleza e do Rio Curiaú. In: Eds. Takiyama L.R., Silva A.Q. Diagnóstico das ressacas do Estado do Amapá: bacias do Igarapé da Fortaleza e Rio Curiaú, Macapá-AP. CPAQ/IEPA e DGEO/ SEMA, Macapá, 1-22.

Violante-González J., Rojas-Herrera A., Aguirre-Macedo M.L. 2008. Seasonal patterns in metazoan parasite community of the "fat sleeper" Dormitator latifrons (Pisces: Eleotridae) from Tres Palos Lagoon, Guerrero, Mexico. Revista de Biologia Tropical, 56, 1419-1427.

Vital J.F., Varella A.M. B., Porto D.B., Malta J.C.O. 2011. Sazonalidade da fauna de metazoários de Pygocentrus nattereri (Kner, 1858) no Lago Piranha (Amazonas, Brasil) e a avaliação de seu potencial como indicadora da saúde do ambiente. Biota Neotropica, 11, 199-204.

Zar J.H. 2010. Biostatistical analysis. 5th ed. Prentice Hall, New Jersey, 944 pp.

Received: August 9, 2013

Revised: November 25, 2013

Accepted for publication: January 16, 2014 